\title{
Impact origin for the greater Ontong Java Plateau?
}

\author{
Stephanie Ingle ${ }^{\mathrm{a}, *}$, Millard F. Coffin ${ }^{\mathrm{b}, \mathrm{c}}$ \\ a Department of Earth and Planetary Sciences, Tokyo Institute of Technology, 2-12-1 Ookayama, Meguro-ku, Tokyo 152-8551, Japan \\ b Ocean Research Institute, University of Tokyo, 1-15-1 Minamidai, Nakano-ku, Tokyo 164-8639, Japan \\ c Institute for Geophysics, Jackson School of Geosciences, University of Texas, 4412 Spicewood Springs Road, Building 600, Austin, \\ TX 78759-8500, USA
}

Received 21 May 2003; received in revised form 14 October 2003; accepted 24 October 2003

\begin{abstract}
The $\sim 120 \mathrm{Ma}$ Ontong Java Plateau and neighboring, contemporaneous Nauru, East Mariana, and (probably) Pigafetta basin flood basalts in the western equatorial Pacific Ocean comprise the Earth's largest flood basalt province. Geophysical, geochemical, and geodynamic evidence from the province are difficult to reconcile with mantle plume models; absence of an obvious hotspot source or track, minor crustal uplift associated with emplacement, minor total subsidence compared with normal oceanic crust or other oceanic plateaus and submarine ridges, high degrees of melting at shallow, upper mantle depths, low water contents of basalts, enrichment of platinum group elements in basalts, and a $\sim 300 \mathrm{~km}$ deep, seismically slow mantle root are more consistent with the consequences of an impacting bolide. An object $\sim 20 \mathrm{~km}$ in diameter impacting relatively young ( $\sim 20 \mathrm{Myr}$ ) Pacific lithosphere and penetrating into the uppermost asthenosphere would have initiated massive decompression melting in the upper mantle, and may have resulted in emplacement of the greater Ontong Java Plateau.
\end{abstract}

(C) 2003 Elsevier B.V. All rights reserved.

Keywords: Ontong Java Plateau; large igneous provinces; bolide impact; mantle plumes; mantle melting; Ocean Drilling Program; Pacific Ocean

\section{Introduction}

Large igneous provinces (LIPs), commonly believed to result from ascending mantle plumes, represent the dominant form of volcanism in

\footnotetext{
* Corresponding author. Formerly at Department of Earth and Environmental Sciences, Université Libre de Bruxelles, Bruxelles, Belgium. Tel.: +81-3-5734-2717;

Fax: +81-3-5734-3538.

E-mail addresses: single@geo.titech.ac.jp (S. Ingle), mcoffin@ori.u-tokyo.ac.jp (M.F. Coffin).
}

our solar system [1]. On Earth, the largest known flood basalt province is the Ontong Java Plateau (OJP), which together with neighboring ocean basin flood basalts comprise the 'greater OJP', encompassing $4.27 \times 10^{6} \mathrm{~km}^{2}$, or $\sim 0.8 \%$, of the Earth's surface (Fig. 1). Emplaced in Early Cretaceous time at $\sim 120 \mathrm{Ma}[2,3]$, the greater OJP's crustal volume is estimated to be $5.8 \times 10^{7} \mathrm{~km}^{3}$ [4,5], with a maximum crustal thickness of $\sim 35$ $\mathrm{km}[5,6]$. Extending beneath the OJP $\sim 300 \mathrm{~km}$ into the mantle is a low-velocity root [6]. Basalts of the greater OJP, sampled from nine Deep Sea Drilling Project (DSDP) and Ocean Drilling Pro- 


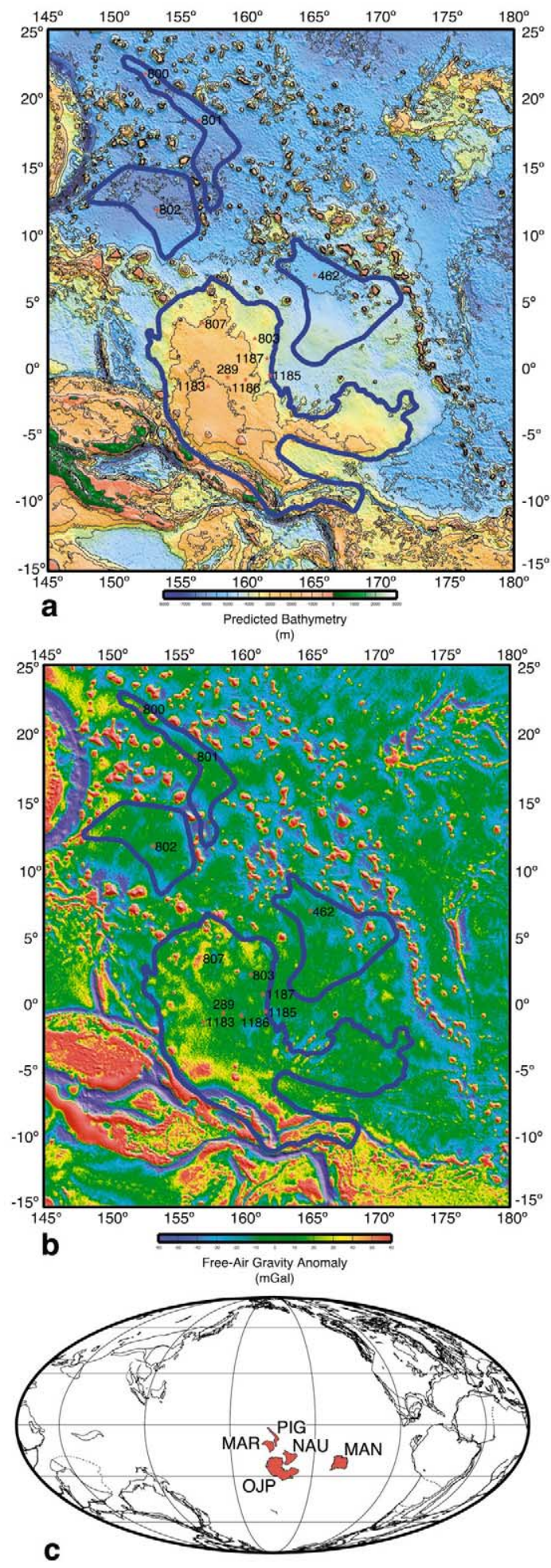

gram (ODP) sites as well as from obducted sections in the Solomon Islands of Malaita and Santa Isabel (Fig. 1a, 1b), are tholeiitic with strikingly uniform petrologic and geochemical characteristics [7-11]. They result from large degrees $(>30 \%)$ of partial melting at shallow upper mantle depths $[2,12,13]$.

Experimental and quantitative modeling of the OJP's emplacement and evolution has focused on one or more ascending mantle plume heads as the underlying mechanism [14-18]. Alternatively, speculation that the OJP formed because of a bolide impact $[19,20]$, or because of a mantle avalanche resulting from a bolide impact [21], has persisted for more than two decades. Here, we evaluate whether mantle plume or impact models are more appropriate for the origin of the greater OJP in light of relevant geophysical, geochemical, and geodynamic evidence.

\section{Evaluation of mantle plume models and the OJP}

Plate tectonic theory does not satisfactorily explain the origin of LIPs, areas of prodigious magmatism recognized by extensive basaltic volcanism [4]. This has led to the proposal that LIPs originate from the heads of mantle plumes arising from deep within the Earth to erupt on the surface by decompression melting [22,23]. Plumes may have a 'tail' that remains 'fixed' to a mantle boundary layer and that feeds the surface, allowing for the plume to erupt continually or sporadically to create long-lived expressions on the surface referred to as hotspots [24]. Although the Louisville hotspot has been suggested as an original source $[23,25]$, the OJP cannot be linked convincingly to it or any other hotspot track or cur-

Fig. 1. The OJP, and the Nauru (NAU), East Mariana (MAR), and Pigafetta (PIG) basin flood basalts in the Pacific Ocean. (a) Predicted bathymetry with drill sites that penetrated flood basalts superimposed [83]; DSDP: Deep Sea Drilling Project; ODP: Ocean Drilling Program. (b) Satellitederived free-air gravity field with same drill sites as (a) superimposed [84]. (c) Plate tectonic reconstruction at $118.7 \mathrm{Ma}$ (chron M0), also showing Manihiki Plateau (MP) (after [85]). 
rently active hotspot on the basis of geochemistry [2], plate reconstructions [12], paleomagnetic data [26], or combined hotspot motion and true polar wander [27].

The a priori assumption that a deep mantle plume created the OJP [28] is based on its huge crustal volume and the unusual conditions required to generate such extensive magmatism. The arrival of hot, buoyant, ascending plume material at the base of oceanic lithosphere, accompanied by voluminous decompression melting, should result in a combination of thermal expansion, buoyant uplift, and crustal growth capable of maintaining the plateau above sea level $[15,17,29]$. Both general isostatic (e.g., [30]) and experimental dynamic plume models (e.g., $[29,31])$ predict that seafloor is uplifted by 1000 $2000 \mathrm{~m}$ due to the arrival of a $1000-2000 \mathrm{~km}$ diameter plume at the base of the lithosphere, in agreement with observations of seafloor swells as-

Fig. 2. Geophysical and geodynamic characteristics of OJP. (a) Model-predicted paleodepths of preexisting oceanic crust (SS92) [35] at time of OJP formation at $\sim 120 \mathrm{Ma}[2,3]$, range of uplift of oceanic crust predicted by specific OJP dynamic (Uplift-Max) [15] and isostatic (Uplift-Min) [17] plume models. For individual DSDP and ODP sites, we compare model-predicted paleodepth ranges for the top of OJP crust (open symbols with bars) to paleodepth ranges of Aptian sediment directly overlying OJP basalts interpreted from paleoenvironmental data (filled symbols with bars) $[13,39,40]$, with elevation of final flood basalt emplacement at $\sim 120$ Ma predicted by either water-corrected isostasy (for calculations below sea level) $\left(\Delta h=\Delta c\left(\rho_{\mathrm{m}}-\rho_{\mathrm{c}}\right) /\left(\rho_{\mathrm{m}}-\rho_{\mathrm{w}}\right)\right)$, or by waterand air-corrected isostasy (for calculations below and above sea level, respectively) $\left(\Delta h=\Delta c\left(\rho_{\mathrm{m}}-\rho_{\mathrm{c}}\right) /\left(\rho_{\mathrm{m}}-\rho_{\mathrm{a}}\right)\right) \quad$ where $\Delta h=$ deviation in height; $\Delta c=$ crustal thickness in excess of normal oceanic crust (7 km [35]); $\rho_{\mathrm{m}}=$ mantle density (3300 $\left.\mathrm{kg} / \mathrm{m}^{3}\right) ; \rho_{\mathrm{c}}=$ crustal density $\left(2800 \mathrm{~kg} / \mathrm{m}^{3}\right) ; \rho_{\mathrm{w}}=$ water density $\left(1030 \mathrm{~kg} / \mathrm{m}^{3}\right)$ below sea level; $\rho_{\mathrm{a}}=$ air density $\left(0 \mathrm{~kg} / \mathrm{m}^{3}\right)$. Crustal thickness values from [5], and ages of preexisting crust estimated from extrapolating Mesozoic marine magnetic anomalies in the Nauru Basin (Fig. 1; [32]). (b) Mass fluxes and peak eruption levels of currently active hotspots and the OJP. Note that of all the hotspots, only Iceland coincides with a mid-ocean ridge. References: Mass flux, OJP (this paper), all others [86], OJP emplacement elevation relative to sea level [13]. For the OJP, the error bars represent the mass flux range assuming an emplacement rate from 1-5 Myr. (c) Total subsidence vs. age for OJP basalts (error bars on symbols denote range interpreted from [39,40,87]). Subsidence curves are from: BL and PS77 [34], and SS92 [35]. sociated with major hotspots (e.g., Hawaii, Cape Verde). Specific OJP plume models, both dynamic [15] and isostatic [17], predict elevation of the seafloor by $3000-4000 \mathrm{~m}$, and $1000-3000 \mathrm{~m}$, respectively (Fig. 2a). The presence of Mesozoic marine magnetic anomalies in the OJP's neighboring Nauru Basin [32] (Fig. 1) suggests that the $\sim 120$ Ma OJP formed within $\sim 130$ to $\sim 155$ Ma [33] oceanic crust. Global age-depth curves [34,35] predict that 10-35 Myr old oceanic crust typically lies at depths of $\sim 3600$ to $\sim 4700 \mathrm{~m}$
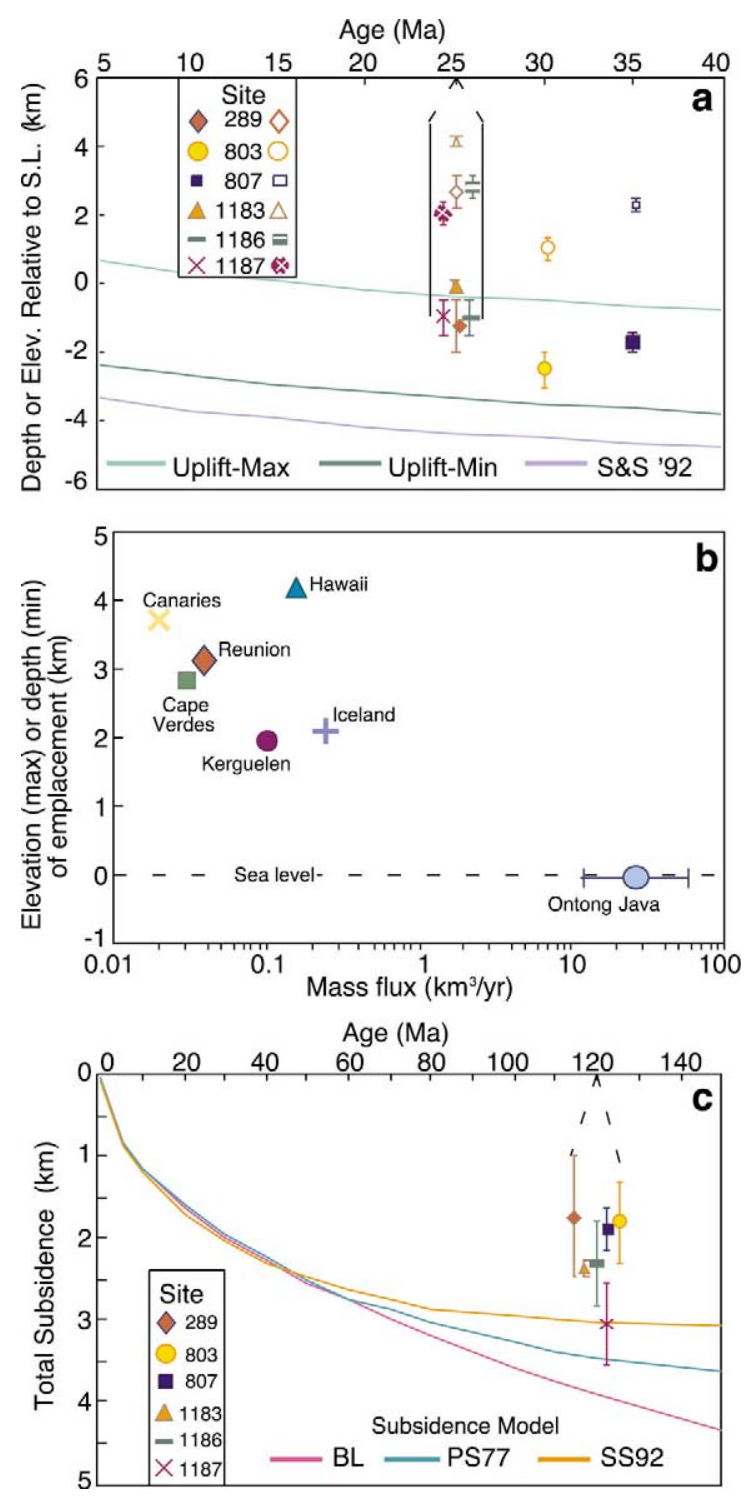
(Fig. 2a). Therefore, according to specific OJP plume models [15,17], oceanic crust should have been uplifted to between $\sim 400 \mathrm{~m}$ above sea level to $\sim 3700 \mathrm{~m}$ below sea level prior to constructional magmatism (Fig. 2a).

According to simple isostasy, emplacement of the OJP's up to $\sim 35 \mathrm{~km}$ thick crust following uplift of preexisting $\sim 7 \mathrm{~km}$ thick oceanic crust [36] should have resulted in major, widespread subaerial volcanism at minimum culminating elevations of $\sim 700$ to $\sim 4200 \mathrm{~m}$ on the central OJP (Fig. 2a). Although no contemporary analogs on such a scale exist, the Earth's six most active hotspots in the ocean basins, characterized by mass fluxes orders of magnitude smaller than the OJP's, all feature large-scale subaerial volcanism (Fig. 2b). Similarly, most oceanic plateaus, submarine ridges, and seamount chains attributed to mantle plumes, and sampled by drilling, have experienced significant subaerial volcanism during construction (e.g., [37,38]). Yet all OJP basalts, either drilled or sampled from obducted Solomon Islands sections, erupted below sea level, and sediments deposited just above this basement are marine [11,13] (Fig. 2b).

Plateaus within oceanic lithosphere should subside via either thermal conduction [30] or continuous viscous spreading of the anomalous mantle material [29]. Many oceanic plateaus and submarine ridges have subsided similarly to oceanic crust of normal thickness [37,38]. Predicted total subsidence of $\sim 120 \mathrm{Ma}$ oceanic crust ranges from $\sim 3000$ to $\sim 3800 \mathrm{~m}[34,35]$. Paleoenvironments interpreted from sediment immediately overlying basalt at five out of six OJP drill sites $[13,39,40]$ and basalt eruption depths calculated from $\mathrm{H}_{2} \mathrm{O}$ and $\mathrm{CO}_{2}$ concentrations in basaltic glasses [41] show that OJP crust, when reconstructed to account for sediment loading, subsided only 1000-2800 m, significantly less than either typical oceanic lithosphere $[34,35]$ or other oceanic plateaus and submarine ridges [37,38,42] (Fig. 2c). Previous geodynamic inferences and models involving subsidence rates typical of most oceanic crust [43] and multiple stages of crustal growth $[17,18]$, respectively, are inconsistent with subsidence determined from sedimentary paleoenvironments as outlined above, and a single major epi- sode of constructional magmatism at $\sim 120 \mathrm{Ma}$ $[2,3]$.

\section{Petrogenesis of greater OJP basalts}

Geochemical similarities among Early Cretaceous tholeiites from the OJP, and the East Mariana and Nauru basins, have led to proposals for a common genetic origin, possibly by an OJP mantle plume [7,9]. Mesozoic magnetic anomalies in the basins indicate that Late Jurassic and Early Cretaceous oceanic crust underlies the Lower Cretaceous East Mariana, Nauru, and Pigafetta flood basalts $[32,44,45]$. Castillo et al. [10] suggested that if one or more OJP plume head(s) had extended underneath these basins, high temperatures induced on preexisting lithosphere arguably could have raised the basalts above the Curie temperature, thus erasing the Mesozoic magnetic anomalies, and suggested that the basin basalts instead originated from isolated Cretaceous rifting events within preexisting Jurassic oceanic crust. However, the OJP, East Mariana, and Nauru basin basalts have similar ages, overlapping isotopic signatures, and generally comparable overall major and trace element compositions [7-10,46,47] and a common mantle origin for the OJP and these basin basalts seems reasonable.

To generate the major and trace element patterns of the greater OJP basalts requires partial batch melting of $30 \%$ or more, followed by extensive fractional crystallization $[2,12,13,48]$. Such large degrees of partial melting are known in seafloor spreading environments influenced by hot or wet mantle plumes $[49,50]$. Primitive mantle-normalized incompatible trace element patterns for greater OJP basalts suggest melting and fractional crystallization at shallow depths, comparable to magma chamber depths of normal mid-ocean ridge basalts (MORB; Fig. 3a). Eruption at ocean ridge crest depths is consistent with the absence of vesicles in greater OJP lavas (indicating minimum eruption depths of $>800 \mathrm{~m}$; [13]), vapor saturation pressures for the basalts indicating eruption depths [41,43], and overlying marine sediments. However, plume theory predicts that emplacement at a ridge would have elevated the OJP 

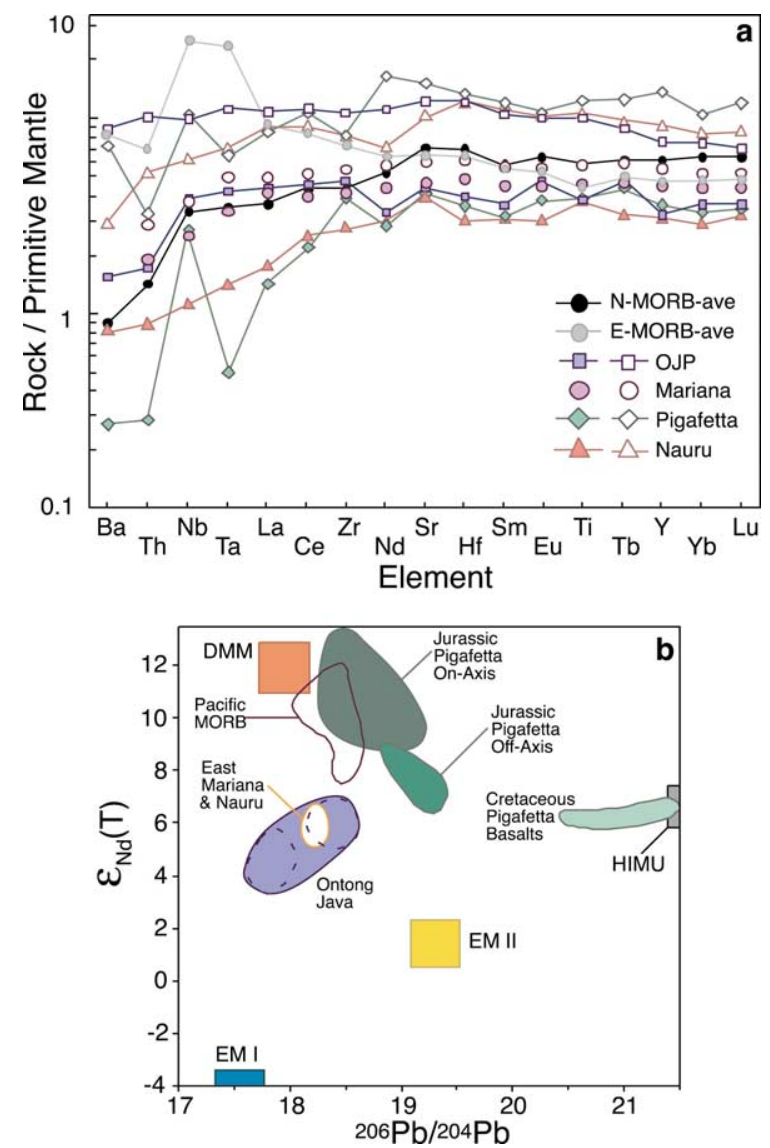

Fig. 3. Geochemical characteristics of the greater OJP basalts. (a) Primitive mantle-normalized [88] incompatible element diagrams for the Lower Cretaceous OJP and East Mariana and Nauru basin basalts [8]. Also shown for comparison are the Jurassic tholeiites from the Pigafetta basin [89], averaged 'normal' N-MORB and 'enriched' E-MORB [88]. Solid symbols represent the lower boundary for each sample suite and open symbols the upper boundary. (b) Age-corrected $\varepsilon_{\mathrm{Nd}}$ versus measured ${ }^{206} \mathrm{~Pb} /{ }^{204} \mathrm{~Pb}$ for the greater OJP and Pigafetta basalts [7-11] and Pacific MORB [90]. Also shown are the values for the mantle end-members [91].

well above sea level [15,17], and this is inconsistent with the absence of vesicles in the basalts and eruption depths determined from vapor saturation pressures, as well as the lack of significant uplift of the OJP. Away from a ridge, extensive melting could be aided if a plume were hydrous [50,51], but concentrations of $\mathrm{H}_{2} \mathrm{O}$ in OJP basalts require a relatively dry mantle source [43].

Radiogenic isotopic compositions ( $\mathrm{Sr}, \mathrm{Nd}$ and $\mathrm{Pb}$ ) of the Early Cretaceous OJP, East Mariana basin, and Nauru basin basalts are unlike presentday Pacific MORB (Fig. 3b). Isotopic values of nearby Jurassic and pre-120 Ma Cretaceous MORB-type Pacific tholeiites (e.g., Jurassic tholeiites in the Pigafetta Basin [9]; Fig. 1a) closely resemble those of modern Pacific MORB. Dissimilar $\mathrm{Sr}-\mathrm{Nd}-\mathrm{Pb}$ isotopic values between greater OJP basalts and pre-120 Ma Pacific tholeiites have been interpreted as precluding MORB-type upper mantle and favoring a plume originating from the lower mantle as the source of the OJP (e.g., [2,9-11,52]). However, isotopic signatures of off-axis Jurassic alkalic basalts from the Pigafetta Basin more closely resemble, although they do not overlap with, those of the OJP, East Mariana basin, and Nauru basin basalts [9]. Cretaceous Pigafetta basin basalts differ from the OJP, East Mariana and Nauru basin basalts, having isotopic compositions that trend between those of the Jurassic alkalic basalts and those of nearby seamounts [9]. The presence of geochemically dissimilar mantle domains in the vicinity of the greater OJP both before and after its emplacement suggests that the off-axis Pacific Ocean upper mantle was quite heterogeneous at local scales during Late Jurassic and Early Cretaceous time.

Platinum group elements (PGEs) are believed to be possible tracers for core input into large mantle plumes ascending from the core-mantle boundary (e.g., [53]). When the Earth formed, these elements were largely stripped from the silicate part of the Earth and incorporated into Earth's core. Therefore, any significant contribution to a plume from the core should be apparent in higher than normal concentrations and distinctive Os isotopic characteristics of the PGEs. PGEs in OJP basalts are high relative to values predicted assuming a primitive mantle source, and a possible, minor core component $(0.5-1 \%)$ has been advocated to account for these elevated concentrations [54,55]. No evidence was found, however, for core input in the Os isotopic compositions of the OJP basalts [56]. Alternatively, to explain the PGE-enriched signatures in OJP basalts, the mantle source could have contained PGE-rich sulfide veins generated by metasomatic fluids derived from ancient continental recycling [57]. However, these fluids would likely leave an 
obvious imprint of the continental signature, as is left in the subcontinental lithospheric mantle [58], and the resulting Os isotopic values should not be primitive mantle like, as the OJP basalts are [56].

\section{Origin of the OJP's mantle root}

The OJP's $300 \mathrm{~km}$ deep low-velocity 'root' $[6,59]$ is the first such observation from an oceanic intraplate setting. A shear wave splitting study concluded that ambient asthenosphere flows around the root, suggesting that it is rheologically strong and attached to the OJP's crust [59]. Centered beneath the OJP's thickest crust, but not extending to underneath the ocean basin flood basalts, the root is cylindrical with a diameter of $\sim 1200 \mathrm{~km}$, and is characterized by anomalously slow $(\sim 5 \%)$ shear wave velocities. If such velocities were entirely thermal in origin, then the root would be up to $700^{\circ} \mathrm{K}$ hotter than surrounding mantle, hot enough to cause continuing volcanism [59]. However, since the OJP shows no evidence of active volcanism, this keel was proposed to more likely represent a chemical heterogeneity $[6,59]$. The root has been interpreted as the frozen head of a plume that somehow failed to remain anchored in the deep mantle [59], but its volume is much larger than can be explained by the volume of mantle remaining from the melt extraction needed to form OJP basalts [12]. Mantle roots characterized by slow seismic velocities have also been detected beneath some continental LIPs, the Deccan Traps [60] and Paraná flood basalts [61], but these are characterized by smaller velocity anomalies (1.5 and $2.4 \%$ vs. 5\%, respectively) than the root beneath the OJP [59].

\section{Impact origin for the OJP?}

Taken in total, many geophysical, geodynamic, and geochemical results from the OJP are at odds with various mantle plume models for its origin. The greater OJP cannot be tied convincingly to any hotspot or hotspot track. Anomalously minor uplift at emplacement and anomalously little subsidence since $120 \mathrm{Ma}$ fit neither plume nor oceanic crustal models, making the OJP the only such anomalous feature identified so far in the ocean basins. High degrees of melting at shallow depths are difficult to reconcile with the likely intraplate emplacement environment and the low water contents in the mantle source. The basalts are geochemically homogeneous compared to other oceanic hotspots and are isotopically similar to some MORB from the Indian Ocean. PGEs are elevated relative to those predicted assuming a primitive mantle source. A low-velocity zone extending $\sim 300 \mathrm{~km}$ into the mantle beneath the OJP has yet to be explained by plume models. As expanded upon below, we suggest that an extraterrestrial impact model is much more consistent with existing data and results.

A large bolide ( $>10 \mathrm{~km}$ in diameter) is required to instigate phenomena such as extensive mantle melting (e.g., [62]). Assuming a chondritic bolide $\sim 20 \mathrm{~km}$ in diameter and vertical impact at a velocity of $20 \mathrm{~km} / \mathrm{s}$, the impact would vaporize the $\sim 4 \mathrm{~km}$ thick water column, probably the entire $\sim 50 \mathrm{~km}$ thick lithosphere, and perhaps part of the uppermost asthenosphere, with a total penetration depth of $\sim 60 \mathrm{~km} \mathrm{[63]} \mathrm{and} \mathrm{a} \mathrm{resulting}$ crater diameter of $\geq 200 \mathrm{~km}$ [64] (Fig. 4a). The impact would generate tsunamis, but the confining $\sim 4 \mathrm{~km}$ thick water barrier surrounding the impact site may have limited the radial distribution of both low- and high-energy impact ejecta (e.g., $[65,66])$. At the time of impact, shock waves imparting intense pressures would propagate hemispherically causing relatively minor shock melting of mantle rock in the wake of the waves [62] (Fig. 4b).

Massive decompression melting of the mantle left surrounding the crater would result from removal of $60 \mathrm{~km}$ of overburden [67], even if the depressurization effect was reduced to some extent by instantaneous lateral resurge partially filling the crater [68]. If $100 \%$ of the mantle melted, following roughly hemispherical patterns outward from the crater, melting to a depth of at least $300 \mathrm{~km}$ would be required (in the case of partial melting, melting to even deeper mantle depths would be required) to explain the greater OJP's crustal volume $\left(5.8 \times 10^{7} \mathrm{~km}^{3}\right)$; such a depth corresponds to the depth of the OJP's tomographi- 

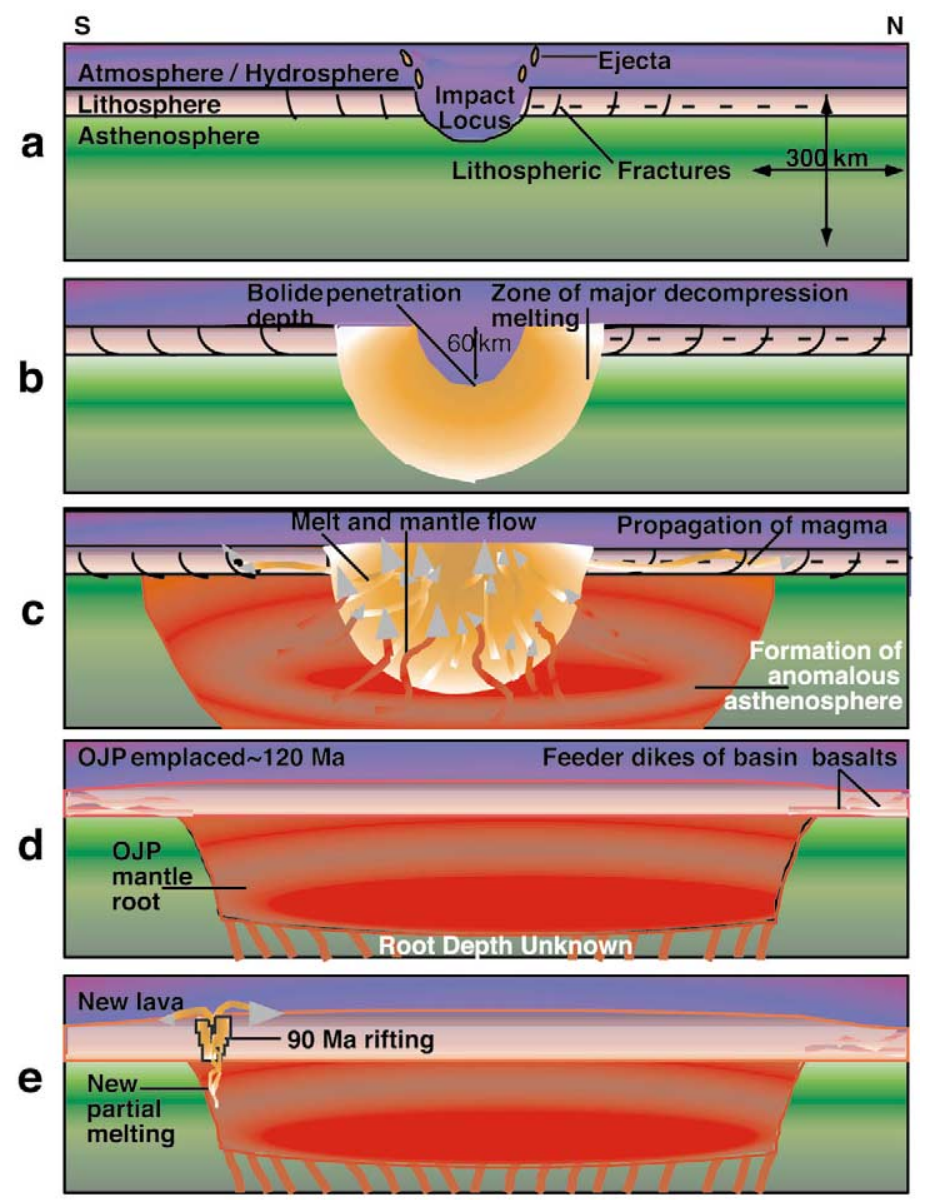

Fig. 4. Conceptual model showing possible sequence of events if an $\sim 20 \mathrm{~km}$ diameter bolide instigated the creation of the OJP. (a) $t_{1}$ Moment of impact, water column is vaporized, $20 \mathrm{Myr}$ old oceanic lithosphere (pink layer) at impact site is obliterated, uppermost asthenosphere is penetrated, and surrounding lithosphere fractures [62]. (b) $t_{2}$ Moment of maximum penetration, the crater is completely formed and melting region becomes focused. (c) $t_{3}$ Infill of void from bottom and sides, melt also migrates out along fractures in lithosphere, refractory surrounding mantle fills space vacated by outflowing magmas. (d) $\sim 120 \mathrm{Ma}$, the OJP at end of emplacement (pink layer represents $\sim 35 \mathrm{~km}$ thick crust). (e) $\sim 90 \mathrm{Ma}$, tectonism causing new pressure release melting. Scale is maintained throughout the diagram.

cally imaged mantle root. Melt would overfill the crater due to thermal expansion, and it would also propagate radially from the crater along fractures created in the brittle, surrounding lithosphere to erupt in the proximal ocean basins (Fig. 4c). Solid mantle, not involved in the melting event, would then both rise buoyantly from beneath and flow from the sides to replace the volume vacated by the erupting, melted mantle (Fig. 4d). Because the melt and underlying solid mantle would ascend adiabatically, with buoyancy generated solely by thermal expansion of ambient mantle (as opposed to excess temperatures and resultant dynamic buoyancy characterizing plumes), relatively minor uplift and subsidence would be associated with emplacement of the greater OJP, and it would be in isostatic equilibrium with surrounding lithosphere [5,18,69] (Fig. 1b).

A large meteorite impact could result in the formation of a temporary magma lake. Such a process may have been common on Earth during heavy meteorite bombardment in Early Archean 
time [70], but has not been proposed for more recent times because of scarce, if any, evidence for large bolides impacting young, thin, and warm lithosphere and penetrating into the uppermost asthenosphere. Large degrees of mantle melting would be expected, creating high-MgO magmas that could undergo extensive differentiation resulting in relatively depleted, Fe-rich, lowpressure lavas. The slight PGE enrichment in some OJP basalts could be explained by minor amounts of condensed bolide material - chondritic meteorites (thought to represent the bulk Earth composition) are enriched, relative to Earth's primitive mantle, in PGEs [71], but have Os isotopic compositions comparable to Earth's primitive mantle [72]. Melting of the upper mantle should result in major and trace element compositions and radiogenic isotopic ratios that reflect those inherent to the melted region. Although greater OJP basalts are comparable in major and trace element compositions to some MORB [2], there is little isotopic similarity between Pacific-type MORB and the greater OJP basalts, which are instead similar to ocean island basalt (OIB). Therefore, the bolide impact might have struck a region of mantle fairly rich in geochemical heterogeneities (i.e. non-MORB-like components). Although the OIB-like isotopic values of the greater OJP basalts are a complication in the bolide impact scenario (see [52] for additional discussion), the average mantle composition, on the scale of the volume of mantle melted - a minimum of 300 $\mathrm{km}$ deep into the mantle - is not sufficiently known to exclude an upper mantle origin for the greater OJP basalts.

Extraction of lavas geochemically similar to greater OJP basalts would generate a highly depleted residuum [73], perhaps comparable to that generated during similar Archean melting events [74]. These depleted restites have relatively low densities but are characterized by higher seismic velocities than normal mantle peridotite [75]. Beneath Pitcairn hotspot, for example, such a highvelocity residue has been detected [76]. Additionally, as stated above, melt extraction (chemical origin) cannot account for the large volume of the OJP's root and a purely thermal origin for the root should result in continued volcanism.
Therefore, we postulate a physical origin for the mantle root - solid mantle that replaced the extracted mantle should have experienced a catastrophic decrease in pressure during its emplacement beneath the OJP. Such 'replacement' mantle would likely have lower shear wave velocities $\left(V_{\mathrm{s}}=(\text { shear modulus/density })^{1 / 2}\right)$ because lowering of ambient mantle pressures has a greater effect on reducing the shear modulus than on modifying the density of the replacement rock [77]. Alternatively, a large meteorite impact could have triggered a mantle avalanche that may have given rise to a large, deep mantle plume [21], but in this case the root should be thermal in origin and the lack of continuous volcanism since $\sim 120$ Ma would be problematic.

The main construction phase of the OJP had ended by $\sim 120 \mathrm{Ma}$ (Fig. 4d). Post-emplacement subsidence of the OJP has been minor, significantly less than normal oceanic lithosphere, because adiabatic (as opposed to dynamically upwelling, thermally anomalous) processes governed the formation of the OJP's crust and its coupled mantle root. We speculate that a regional tectonic event affected the southeastern portion of the OJP at $\sim 90 \mathrm{Ma}-$ contemporaneous with the proposed opening of the Ellice Basin to the east [12] - resulting in rifting, decompression melting in the mantle root formed as a result of the $\sim 120$ Ma impact, and lava emplacement as the relatively minor (by volume) $\sim 90 \mathrm{Ma}$ basalts (Fig. 4e). Tapping previously unmelted mantle, from a source similar to that which generated the $\sim 120$ Ma lavas, during the $\sim 90$ Ma rifting could also account for the near-identical geochemistry of the $\sim 120$ and $\sim 90$ Ma basalts.

\section{Possibilities for testing an impact model}

On the basis of current geophysical and geochemical data, an impact model for the origin of the greater OJP warrants further testing (see also [52]). Quantitative modeling of the impact event, including evolution of the crater morphology, of melt volumes and compositions induced by the impact, of emplacement of the melt, and of OJP uplift and subsidence is critically needed to assess 
the viability of the model. Samples from deeper in the OJP's crustal section are critical for further evaluating the geochemical homogeneity observed in the uppermost crustal basalts, and for determining the duration of the $\sim 120$ Ma event and the volume of the $\sim 90 \mathrm{Ma}$ event. Also needed are more primitive samples for PGE and other highly siderophile element analyses, with emphasis on isotopic systems sensitive to core and/or meteorite involvement $(\mathrm{Cr}$, Os and $\mathrm{W})$. Additional samples from the East Mariana, Nauru, and Pigafetta basin flood basalts, each currently penetrated at a single drill site, are needed to test age and geochemical relationships to OJP rocks. Distal, or even global evidence of an impact could include tsunami-related deposits on land, disturbed abyssal sediments of early Aptian age, and shocked minerals, tektites, spherules, and Ir anomalies in early Aptian terrigenous and marine sediments.

\section{Implications of an impact model}

Aptian time, coinciding with the emplacement of the greater OJP, is marked by major global events that include onset of the Cretaceous normal magnetic polarity superchron [28], the Selli oceanic anoxic event [78], significant marine faunal extinctions $[79,80]$, and a worldwide radiogenic $\mathrm{Sr}$ isotopic excursion in marine sediments that suggests a rapid change from terrigenous-dominated values to mantle-dominated values [81]. Furthermore, we note that the approximately contemporaneous Manihiki Plateau (Fig. 1c) shares some geochemical characteristics with the greater OJP $[7,46]$. We suggest that a major bolide impact could have caused or contributed to such phenomena, although analyses thereof are beyond the scope of this study. The absence of recognized impact craters on Earth's deep ocean floor is remarkable considering that estimates based on the present-day terrestrial cratering rate predict that up to three $\sim 10 \mathrm{~km}$ diameter bolides should have struck the deep ocean basins in post-Jurassic times [82]. The OJP and the neighboring ocean basin flood basalts show evidence of possibly resulting from one such impact.

\section{Note added in proof}

Shear velocity and attenuation characteristics of the OJP's anomalous mantle root determined from analyses of multiple $\mathrm{ScS}$ earthquake phases rule out a thermal anomaly as its cause [92], further supporting the idea that the keel represents a chemical heterogeneity [6,59].

\section{Acknowledgements}

We thank our colleagues and the crew aboard Ocean Drilling Program Leg 192; J.J. Mahoney for extensive discussions; and J.J. Mahoney, A.P. Jones, P. Claeys and an anonymous reviewer for their comments on various versions of this manuscript. We appreciate fruitful discussions with A. Davaille, L. Elkins Tanton, C. Farnetani, D. Forsythe, G. Ito, A. Jones, S. King, T. Kleine, P. Michael, F. Nauret, E. Okal, I. Parkinson, D. Price, M. Rampino, C. Raymond, T. Sano, H. Senshu, V. Shuvalov, E. Takahashi, M. Warner and H. Weissert. T. Kleine and C. Neal provided helpful reprints; L. Gahagan (PLATES project) Cretaceous plate reconstructions; and T. Gladczenko and R. Miura able technical assistance. This study used data acquired by the Ocean Drilling Program (ODP). The ODP was funded by the U.S. National Science Foundation (NSF) and member countries, and managed by the Joint Oceanographic Institutions (JOI). S.I. was supported by an ARC grant from the Communauté Française de Belgique (\#98-03/233); M.F.C. by grants from NSF, JOI/U.S. Science Support Program, and the Japanese Ministry of Education, Culture, Sports, Science, and Technology (MEXT). UTIG contribution \#1679.[SK]

\section{References}

[1] J.W. Head, III, M.F. Coffin, Large igneous provinces: a planetary perspective, in: J. Mahoney, M.F. Coffin (Eds.), Large Igneous Provinces: Continental, Oceanic, and Planetary Flood Volcanism, Geophys. Monogr. 100, AGU, Washington, DC, 1997, pp. 411-438.

[2] J.J. Mahoney, M. Storey, R.A. Duncan, K.J. Spencer, M.S. Pringle, Geochemistry and age of the Ontong Java 
Plateau, in: M.S. Pringle, W.W. Sager, W. Sliter, S. Stein (Eds.), The Mesozoic Pacific. Geology, Tectonics, and Volcanism, Geophys. Monogr. 77, AGU, Washington, DC, 1993, pp. 233-261.

[3] L. Chambers, M.S. Pringle, J.G. Fitton, Age and duration of magmatism on the Ontong Java Plateau, Geophys. Res. Abstr. 5 (2003) 09657.

[4] M.F. Coffin, O. Eldholm, Large igneous provinces: crustal structure, dimensions, and external consequences, Rev. Geophys. 32 (1994) 1-36.

[5] T.P. Gladczenko, M.F. Coffin, O. Eldholm, Crustal structure of the Ontong Java Plateau: modeling of new gravity and existing seismic data, J. Geophys. Res. 102 (1997) 22711-22729.

[6] W.P. Richardson, E.A. Okal, S. Van der Lee, Rayleighwave tomography of the Ontong-Java Plateau, Phys. Earth Planet. Int. 118 (2000) 29-51.

[7] J.J. Mahoney, An isotopic survey of Pacific oceanic plateaus: implications for their nature and origin, in: B.H. Keating, P. Fryer, R. Batiza, G.W. Boehlert (Eds.), Seamounts, Islands, and Atolls, Geophys. Monogr. 43, AGU, Washington, DC, 1987, pp. 207-220.

[8] P.R. Castillo, R.L. Carlson, R. Batiza, Origin of Nauru Basin igneous complex: $\mathrm{Sr}, \mathrm{Nd}$ and $\mathrm{Pb}$ isotope and REE constraints, Earth Planet. Sci. Lett. 103 (1991) 200-213.

[9] P.R. Castillo, P.A. Floyd, C. France-Lanord, Isotope geochemistry of Leg 129 basalts: implications for the origin of the widespread Cretaceous volcanic event in the Pacific, in: R.L. Larson, Y. Lancelot et al. (Eds.), Proc. ODP Sci. Results 129 (1992) 405-413.

[10] P.R. Castillo, M.S. Pringle, R.W. Carlson, East Mariana Basin tholeiites: Cretaceous intraplate basalts or rift basalts related to the Ontong Java plume, Earth Planet. Sci. Lett. 123 (1994) 139-154.

[11] M.L.G. Tejada, J.J. Mahoney, C.R. Neal, R.A. Duncan, M.G. Petterson, Basement geochemistry and geochronology of Central Malaita, Solomon Islands, with implications for the origin and evolution of the Ontong Java Plateau, J. Petrol. 43 (2002) 449-484.

[12] C.R. Neal, J.J. Mahoney, L.W. Kroenke, R.A. Duncan, M.G. Petterson, The Ontong Java Plateau, in: J. Mahoney, M.F. Coffin (Eds.), Large Igneous Provinces: Continental, Oceanic, and Planetary Flood Volcanism, Geophys. Monogr. 100, AGU, Washington, DC, 1997, pp. 183-216.

[13] Shipboard Scientific Party, Leg 192 summary, in: J.J. Mahoney, J.G. Fitton, P.J. Wallace et al. (Eds.), Proc. ODP Init. Rep. 192 (2001) 1-75.

[14] D. Bercovici, J. Mahoney, Double flood basalts and plume head separation at the 660-kilometer discontinuity, Science 266 (1994) 1367-1369.

[15] C.G. Farnetani, M.A. Richards, Numerical investigations of the mantle plume initiation model for flood basalt events, J. Geophys. Res. 99 (1994) 13813-13833.

[16] C.G. Farnetani, M.A. Richards, M.S. Ghiorso, Petrological models of magma evolution and deep crustal struc- ture beneath hotspots and flood basalt provinces, Earth Planet. Sci. Lett. 143 (1996) 81-94.

[17] G. Ito, P.D. Clift, Subsidence and growth of Pacific Cretaceous plateaus, Earth Planet. Sci. Lett. 161 (1998) 85100.

[18] G. Ito, A. Taira, Compensation of the Ontong Java Plateau by surface and subsurface loading, J. Geophys. Res. 105 (2000) 11171-11183.

[19] G.C. Rogers, Oceanic plateaus as meteorite impact signatures, Nature 299 (1982) 341-342.

[20] N.J. Price, Major Impacts and Plate Tectonics: A Model for the Phanerozoic Evolution of the Earth's Lithosphere, Routledge, London, 2001, 354 pp.

[21] R.A. Muller, Avalanches at the core-mantle boundary, Geophys. Res. Lett. 29 (2002) doi: 10.1029/ 2002GL015938.

[22] J.W. Morgan, Hotspot tracks and the opening of the Atlantic and Indian Oceans, in: C. Emiliani (Ed.), The Sea 7, The Oceanic Lithosphere, Wiley, New York, 1981, pp. 443-487.

[23] M.A. Richards, R.A. Duncan, V. Courtillot, Flood basalts and hotspot tracks: plume heads and tails, Science 246 (1989) 103-107.

[24] W.J. Morgan, Plate motions and deep mantle convection, Geol. Soc. Am. Mem. 132 (1972) 7-22.

[25] E.J. Phinney, P. Mann, M.F. Coffin, T.H. Shipley, Sequence stratigraphy, structure, and tectonic history of the southwestern Ontong Java Plateau adjacent to the North Solomon Trench and Solomon Islands arcs, J. Geophys. Res. 104 (1999) 20449-20466.

[26] P. Riisager, S. Hall, M. Antretter, X. Zhao, Paleomagnetic paleolatitude of Early Cretaceous Ontong Java Plateau basalts: implications for Pacific apparent and true polar wander, Earth Planet. Sci. Lett. 208 (2003) 235-252.

[27] M. Antretter, P. Riisager, S. Hall, X. Zhao, B. Steinberger, Modeled palaeolatitudes for the Louisville hotspot and the Ontong Java Plateau, in: J.G. Mahoney, P.J. Wallace, A.D. Saunders (Eds.), Origin and Evolution of the Ontong Java Plateau, Geol. Soc. London Spec. Publ., in press.

[28] J.A. Tarduno, W.V. Sliter, L.W. Kroenke, M. Leckie, H. Mayer, J.J. Mahoney, R. Musgrave, M. Storey, E.L. Winterer, Rapid formation of Ontong Java Plateau by Aptian mantle plume volcanism, Science 254 (1991) 399-403.

[29] R.W. Griffiths, M. Gurnis, G. Eitelberg, Holographic measurements of surface topography in laboratory models of mantle hotspots, Geophys. J. 96 (1989) 477-495.

[30] R.S. Detrick, S.T. Crough, Island subsidence, hot spots, and lithospheric thinning, J. Geophys. Res. 83 (1978) 1236-1244.

[31] P. Olson, I.S. Nam, Formation of seafloor swells by mantle plumes, J. Geophys. Res. 91 (1986) 7181-7191.

[32] M. Nakanishi, E.L. Winterer, Tectonic history of the Pacific-Farallon-Phoenix triple junction from Late Jurassic to Early Cretaceous: an abandoned Mesozoic spreading system in the central Pacific basin, J. Geophys. Res. 103 (1998) 12453-12468. 
[33] F.M. Gradstein, F.P. Agterberg, J.G. Ogg, J. Hardenbol, P. van Veen, J. Thierry, Z. Huang, A Mesozoic time scale, J. Geophys. Res. 99 (1994) 24051-24074.

[34] B. Parsons, J.G. Sclater, An analysis of the variation of ocean floor bathymetry and heat flow with age, J. Geophys. Res. 82 (1997) 803-827.

[35] C.A. Stein, S. Stein, A model for the global variation in oceanic depth and heat flow with lithospheric age, Nature 359 (1992) 123-129.

[36] R.S. White, D. McKenzie, R.K. O'Nions, Oceanic crustal thickness from seismic measurements and rare earth element inversions, J. Geophys. Res. 97 (1992) 19683-19715.

[37] R.S. Detrick, J.G. Sclater, J. Thiede, The subsidence of aseismic ridges, Earth Planet. Sci. Lett. 34 (1997) 185-196.

[38] M.F. Coffin, Emplacement and subsidence of Indian Ocean plateaus and submarine ridges, in: R.A. Duncan, D.K. Rea, R.B. Kidd, U. von Rad, J.K. Weissel (Eds.), Synthesis of Results from Scientific Drilling in the Indian Ocean, Geophys. Monogr. 70, AGU, Washington, DC, 1992, pp. 115-125.

[39] J.E. Andrews, G. Packham et al. (Eds.), Deep Sea Drilling Program Initial Reports, vol. 30, U.S. Government Printing Office, Washington, DC, 1975.

[40] W.M. Sliter, R.M. Leckie, Cretaceous planktonic foraminifers and depositional environments from the Ontong Java Plateau with emphasis on Sites 803 and 807, in: L.W. Kroenke, W.H. Berger, T.R. Janacek et al. (Eds.), Proc. ODP Init. Rep. 130 (1993) 63-84.

[41] J. Roberge, R.V. White, P.J. Wallace, M.F. Coffin, Anomalous subsidence of the Ontong Java Plateau (ODP Leg 192), EOS Trans. Am. Geophys. Union 84 (46) (2003) F1490.

[42] P.J. Wallace, Volatiles in submarine basaltic glasses from the Northern Kerguelen Plateau (ODP Site 1140): implications for source region compositions, magmatic processes, and plateau subsidence, J. Petrol. 43 (2002) 1311-1326.

[43] P.J. Michael, Implications for magmatic processes at Ontong Java Plateau from volatile and major element contents of Cretaceous basalt glasses, Geochem. Geophys. Geosyst. 1 (1999) doi: 1999GC000025.

[44] L.J. Abrams, R.L. Larson, T.H. Shipley, Y. Lancelot, Cretaceous volcanic sequences and Jurassic oceanic crust in the East Mariana and Pigafetta Basins of the Western Pacific, in: M.S. Pringle, W.W. Sager, W. Sliter, S. Stein (Eds.), The Mesozoic Pacific. Geology, Tectonics, and Volcanism, Geophys. Monogr. 77, AGU, Washington, DC, 1993, pp. 77-101.

[45] T.H. Shipley, L.J. Abrams, Y. Lancelot, R.L. Larson, R.L. Larson, Late Jurassic-Early Cretaceous oceanic crust and Early Cretaceous volcanic sequences of the Nauru Basin, Western Pacific, in: M.S. Pringle, W.W. Sager, W. Sliter, S. Stein (Eds.), The Mesozoic Pacific. Geology, Tectonics, and Volcanism, Geophys. Monogr. 77, AGU, Washington, DC, 1993, pp. 103-119.

[46] J.J. Mahoney, K.J. Spencer, Isotopic evidence for the origin of the Manihiki and Ontong Java oceanic plateaus, Earth Planet. Sci. Lett. 104 (1991) 196-210.
[47] M.S. Pringle, Radiometric ages of basaltic basement recovered at Sites 800, 801, and 802, Leg 129, western Pacific Ocean, in: R.L. Larson, Y. Lancelot et al. (Eds.), Proc. ODP. Sci. Results 129 (1992) 389-404.

[48] J.G. Fitton, M. Godard, Origin and evolution of magmas on the Ontong Java Plateau, in: J.G. Fitton, J.J. Mahoney, P.J. Wallace, A.D. Saunders (Eds.), Origin and Evolution of the Ontong Java Plateau, Geol. Soc. London Spec. Publ., in press.

[49] J.-G. Schilling, Fluxes and excess temperatures of mantle plumes inferred from their interaction with migrating midocean ridges, Nature 352 (1991) 397-403.

[50] A.R.L. Nicols, M.R. Carroll, A. Höskuldsson, Is the Iceland hot spot also wet? Evidence from the water contents of undegassed submarine and subglacial pillow basalts, Earth Planet. Sci. Lett. 202 (2002) 77-87.

[51] E. Bonatti, Not so hot 'hot spots' in the oceanic mantle, Science 250 (1990) 107-110.

[52] M.L.G. Tejada, J.J. Mahoney, P.R. Castillo, S. Ingle, H.C. Sheth, D. Weis, Pin-pricking the elephant (ODP Leg 192): $\mathrm{Pb}-\mathrm{Sr}-\mathrm{Hf}-\mathrm{Nd}$ isotopic evidence on the origin of the Ontong Java Plateau, in: J.G. Fitton, J.J. Mahoney, P.J. Wallace, A.D. Saunders (Eds.), Origin and Evolution of the Ontong Java Plateau, Geol. Soc. London Spec. Publ., in press.

[53] D. Walker, Core participation in mantle geochemistry: Geochemical Society Ingerson Lecture, GSA Denver, October 1999, Geochim. Cosmochim. Acta 64 (2000) 28972911.

[54] J.C. Ely, C.R. Neal, Using platinum group elements to investigate the origin of the Ontong Java Plateau, SW Pacific Ocean, Chem. Geol. 196 (2003) 235-257.

[55] W.J. Chazey, C.R. Neal, LIP magma petrogenesis from source to surface: platinum-group element evidence from Ontong Java Plateau basalts recovered during ODP Leg 192, in: J.G. Fitton, J.J. Mahoney, P.J. Wallace, A.D. Saunders (Eds.), Origin and Evolution of the Ontong Java Plateau, Geol. Soc. London Spec. Publ., in press.

[56] I.J. Parkinson, B.F. Schaefer, the ODP Leg 192 Shipboard Scientific Party, A lower mantle origin for the world's biggest LIP? A high precision Os isotope isochron from Ontong Java Plateau basalts drilled on ODP Leg 192, EOS Trans. Am. Geophys. Union 82 (47) (2001) F1398.

[57] O. Alard, W.L. Griffin, J.P. Lorand, S.E. Jackson, S.Y. O'Reilly, Non-chondritic distribution of the highly siderophile elements in mantle sulphides, Nature 407 (2000) 891-894.

[58] O. Alard, W.L. Griffin, N.J. Pearson, J.-P. Lorand, S.Y. O'Reilly, New insights into the Re-Os systematics of subcontinental lithospheric mantle from in situ analysis of sulphides, Earth Planet. Sci. Lett. 203 (2002) 651-663.

[59] E.R. Klosko, R.M. Russo, E.A. Okal, W.P. Richardson, Evidence for a rheologically strong chemical mantle root beneath the Ontong-Java Plateau, Earth Planet. Sci. Lett. 186 (2001) 347-361.

[60] B.L.N. Kennett, S. Widiyantoro, A low seismic wave- 
speed anomaly beneath northwestern India: a seismic signature of the Deccan plume?, Earth Planet. Sci. Lett. 165 (1999) 145-155.

[61] J.C. VanDecar, D.E. James, Seismic evidence for a fossil mantle plume beneath South America and implications for plate driving forces, Nature 378 (1995) 25-31.

[62] A.P. Jones, G.D. Price, N.J. Price, P.S. DeCarli, R.A. Clegg, Impact induced melting and the development of large igneous provinces, Earth Planet. Sci. Lett. 202 (2002) 551-561.

[63] J.D. O'Keefe, T.J. Ahrens, Planetary cratering mechanics, J. Geophys. Res. 98 (1993) 17011-17028.

[64] R.A.F. Grieve, L.J. Pesonen, The terrestrial impact cratering record, Tectonophysics 216 (1992) 1-30.

[65] H.J. Melosh, N.M. Schneider, K.J. Zahnle, D. Latham, Ignition of global wildfires at the Cretaceous-Tertiary boundary, Nature 343 (1990) 251-254.

[66] D.A. Kring, D.D. Durda, Trajectories and distribution of material ejected from the Chicxulub impact crater: Implications for post-impact wildfires, J. Geophys. Res. 107 (E6) (2002) doi: 10.1029/2001JE001532.

[67] A.Y. Glikson, Oceanic mega-impacts and crustal evolution, Geology 27 (1999) 387-390.

[68] B.A. Ivanov, H.J. Melosh, Impacts do not initiate volcanic eruptions: eruptions close to the crater, Geology 31 (2003) 869-872.

[69] A.S. Furumoto, D.M. Hussong, J.F. Campbell, G.H. Sutton, A. Malahoff, J.C. Rose, G.P. Woodlard, Crustal and upper mantle structure of the Solomon Islands as revealed by seismic refraction survey of November-December 1966, Pacific Sci. 24 (1970) 315-332.

[70] W.B. Tonks, H.J. Melosh, Magma ocean formation due to giant impacts, J. Geophys. Res. 98 (1993) 5319-5333.

[71] E. Anders, N. Grevesse, Abundances of the elements: meteoritic and solar, Geochim. Cosmochim. Acta 53 (1989) 197-214.

[72] S.B. Shirey, R.J. Walker, The Re-Os isotope system in cosmochemistry and high-temperature geochemistry, Annu. Rev. Earth Planet. Sci. 26 (1998) 423-500.

[73] E. Takahashi, Melting of a dry peridotite KLB-1 to 14 GPa: implications on the origin of peridotitic upper mantle, J. Geophys. Res. 91 (1986) 9367-9382.

[74] E. Takahashi, Speculations on the Archean mantle: missing link between komatiite and depleted garnet peridotite, J. Geophys. Res. 95 (1990) 15941-15956.

[75] Y.-S. Zhang, T. Tanimoto, High-resolution global upper mantle structure and plate tectonics, J. Geophys. Res. 98 (1993) 9793-9823.

[76] S. Rost, Q. Williams, Seismic detection of sublithospheric plume head residue beneath the Pitcairn hot-spot chain, Earth Planet. Sci. Lett. 209 (2003) 71-83.

[77] S.V. Sinogeikin, J.D. Bass, T. Katsura, Single-crystal elasticity of ringwoodite to high pressures and high temperatures: implications for $520 \mathrm{~km}$ seismic discontinuity, Phys. Earth Planet. Int. 136 (2003) 41-66.
[78] R.L. Larson, E. Erba, Onset of the mid-Cretaceous greenhouse in the Barremian-Aptian: igneous events and the biological, sedimentary, and geochemical responses, Paleoceanography 14 (1999) 663-678.

[79] J.J. Sepkoski, Periodicity in extinction and the problem of catastrophism in the history of life, J. Geol. Soc. London 146 (1989) 7-19.

[80] J.J. Sepkoski, The taxonomic structure of periodic extinction, in: V.L. Sharpton, P.D. Ward (Eds.), Global Catastrophes in Earth History: An Interdisciplinary Conference on Impacts, Volcanism, and Mass Mortality, Geol. Soc. Am. Spec. Publ. 247, 1990, pp. 33-44.

[81] C.E. Jones, H.C. Jenkyns, Seawater strontium isotopes, oceanic anoxic events, and seafloor hydrothermal activity in the Jurassic and Cretaceous, Am. J. Sci. 301 (2001) 112-149.

[82] A. Proveda, M.A. Herrera, J.L. Garcia, K. Curioca, The diameter distribution of Earth-crossing asteroids, Planet. Space Sci. 47 (1999) 679-685.

[83] W.H.F. Smith, D.T. Sandwell, Global seafloor topography from satellite altimetry and ship depth soundings, Science 277 (1997) 1956-1962.

[84] D.T. Sandwell, W.H.F. Smith, Marine gravity anomaly from Geosat and ERS-1 satellite altimetry, J. Geophys. Res. 102 (1997) 10039-10054.

[85] O. Eldholm, M.F. Coffin, Large igneous provinces and plate tectonics, in: M.A. Richards, R.G. Gordon, R.D. van der Hilst (Eds.), The History and Dynamics of Global Plate Motions, Geophys. Monogr. 121, AGU, Washington, DC, 2000, pp. 309-326.

[86] R.S. White, Melt production rates in mantle plumes, Philos. Trans. R. Soc. London 342 (1993) 137-153.

[87] J.J. Mahoney, J.G. Fitton, P.J. Wallace et al. (Eds.), Proceedings Ocean Drilling Program Initial Reports, vol. 192, 2001 [CD-ROM].

[88] S.-s. Sun, W.F. McDonough, Chemical and isotopic systematics of oceanic basalts: implications for mantle composition and processes, in: A. Saunders, M. Norry (Eds.), Magmatism in the Ocean Basins, Geol. Soc. London Spec. Publ. 42, 1989, pp. 313-345.

[89] P.A. Floyd, P.R. Castillo, Geochemistry and petrogenesis of Jurassic ocean crust basalts, Site 801, in: R.L. Larson, Y. Lancelot et al. (Eds.), Proc. ODP Sci. Results 129 (1992) 361-388.

[90] P.R. Castillo, E. Klein, J. Bender, C. Langmuir, S. Shirey, R. Batiza, W. White, Petrology and $\mathrm{Sr}, \mathrm{Nd}$, and $\mathrm{Pb}$ isotope geochemistry of mid-ocean ridge basalt glasses from the $11^{\circ} 45^{\prime} \mathrm{N}$ to $15^{\circ} 00^{\prime} \mathrm{N}$ segment of the East Pacific Rise, Geochem. Geophys. Geosyst. 1 (2000) doi: 1029/ 1999GC000024.

[91] A. Zindler, S. Hart, Chemical geodynamics, Annu. Rev. Earth Planet. Sci. 14 (1986) 493-571.

[92] B.M. Gomer, E.A. Okal, Multiple-ScS probing of the Ontong-Java Plateau, Phys. Earth Planet. Int. 138 (2003) 317-331. 